\title{
Pemanfaatan Informasi Spasial Berbasis SIG untuk Pemetaan Tingkat Kerawanan Longsor di Kabupaten Bandung Barat, Jawa Barat
}

\author{
Arnas Hardianto ${ }^{1 *}$, Denta Winardi ${ }^{1}$, Deamasari Dwi Rusdiana ${ }^{1}$, Aryka Claudia Eka Putri ${ }^{1}$, Febriyan \\ Ananda $^{1}$, Devitasari ${ }^{1}$, Faturrahman Saleh Djarwoatmodjo ${ }^{1}$, Felia Yustika', Febryan Gustav ${ }^{2}$ \\ ${ }^{1}$ Jurusan Teknik Geofisika, Fakultas Teknik, Universitas Lampung, Jl. Prof. Dr. Ir. Sumantri Brojonegoro, Bandar Lampung, \\ Lampung 35141 \\ ${ }^{2}$ Departemen Fisika, Fakultas Sains dan Matematika, Universitas Diponegoro, Jl. Prof Soedarto, SH Tembalang, \\ Semarang 50275
}

Dikirim:
10 April 2020
Direvisi:
30 April 2020
Diterima:
1 Mei 2020
*Email Korespondensi:
arnashardianto32@gmail.com
20) (i) (0)

Abstrak: Provinsi Jawa Barat merupakan daerah dengan dominasi perbukitan sehingga sering terjadi peristiwa tanah longsor pada lereng yang menutupi badan jalan, terutama di musim hujan sehingga menambah beban lereng dan lapisan tanah mengalami penurunan kuat. Penelitian ini bertujuan untuk memetakan tingkat kerawanan bencana tanah longsor di Kabupaten Bandung Barat, Jawa Barat dengan memanfaatkan informasi spasial berbasis SIG sehingga dapat menjadi acuan dalam melakukan mitigasi bencana tanah longsor. Metode yang digunakan dalam penelitian ini adalah metode overlay di mana setiap parameter diberi skor masingmasing dan kemudian dilakukan pembobotan. Dari hasil pembobotan ini kemudian diperoleh tingkat kerawanan bencana tanah longsor pada daerah penelitian. Adapun parameter yang digunakan yaitu peta tutupan lahan, peta jenis tanah, peta kemiringan lereng, peta curah hujan dan peta jenis batuan. Hasil penelitian ini menunjukkan bahwa daerah Kabupaten Bandung Barat memiliki kerawanan terjadinya tanah longsor dengan tingkat rendah, sedang, tinggi dan sangat tinggi. Untuk tingkat kerawanan longsor rendah terdapat pada 4 kecamatan, kerawanan longsor sedang pada 7 kecamatan, kerawanan longsor tinggi pada 12 kecamatan, dan kerawanan longsor sangat tinggi pada 3 kecamatan.

Kata kunci: bencana, longsor, mitigasi, pemetaan, sistem informasi geografis

\begin{abstract}
West Java Province is an area dominated by hill so landslides often occur on slopes that cover the road body, especially in the rainy season so that increasing the burden of slopes and soil layers experience a strong decline. This study aims to map the level of landslide disaster vulnerability in West Bandung Regency, West Java by utilizing GIS-based spatial information so that it can be a reference in mitigating landslides. The method used in this study is the overlay method where each parameter is given a score of each and then weighted. From the results of this weighting, the level of landslide disaster in the study area is then obtained. The parameters used are land cover map, land type map, slope map, rainfall map and rock type map. The results of this study indicate that the area of West Bandung Regency has low, medium, high and very high landslides. The level of landslide vulnerability is low in 4 districts, moderate landslide vulnerability in 7 districts, landslide hazard is high in 12 districts, and landslide hazard is very high in 3 districts.
\end{abstract}

Keywords: disaster, geographical information system, landslide, mapping, mitigation

\section{PENDAHULUAN}

Bencana tanah longsor telah mengakibatkan lebih banyak kerugian dibandingkan dengan bencana lainnya. Setiap tahun, kasus bencana tanah longsor semakin meningkat terutama saat memasuki musim hujan terutama di daerah-daerah perbukitan terjal. Berdasarkan data, tercatat kejadian bencana tanah longsor terjadi pada 809 lokasi di seluruh wilayah Indonesia yang memakan korban jiwa 2484 orang meninggal dunia (PVMBG, 2012).

Potensi terjadinya bencana alam pada dasarnya merupakan suatu gambaran fenomena alam yang khas terutama untuk wilayah Indonesia yang secara geografis memiliki bentang alam yang kompleks. Indonesia berada pada lokasi yang strategis yang diapit oleh tiga lempeng besar dunia, yaitu lempeng Indo-Australia, Eurasia dan Pasifik.

Rahman dkk., (2014) menyampaikan bahwa selain iklim dan geotektonik, faktor manusia yaitu aktivitas manusia di atas lahan yang membebani lereng juga berkontribusi dalam terjadinya tanah longsor. Tanah longsor atau gerakan tanah merupakan peristiwa yang terjadi akibat pergerakan massa batuan ataupun tanah. Tanah longsor sering terjadi di Indonesia dan mengakibatkan kerugian baik material ataupun non material. Nugroho (2016) mengatakan bahwa di Indonesia telah terjadi 1.681 kasus bencana alam yang memakan korban sebanyak 259 jiwa, di mana sebagian besar merupakan korban bencana tanah longsor. Bencana tanah longsor dapat dipengaruhi oleh berbagai faktor, baik secara alami maupun akibat kondisi sosial. Selain faktor alam, ternyata faktor sosial yang terjadi di masyarakat juga perlu dikaji dalam mengidentifikasi bencana alam.

Tanah longsor adalah peristiwa alam di mana satu massa tergelincir terhadap massa yang lain, disebabkan oleh tidak kuatnya gaya lekat (resisting force) antar lapisan tanah dalam menahan perubahan massa tersebut (Sudibyo, 2017). Tanah longsor terjadi karena terganggunya kestabilan tanah atau batuan penyusun lereng. Gangguan ter- 
sebut dapat dikontrol oleh kondisi morfologi (kemiringan lereng), kondisi hidrologi, dan kondisi batuan/tanah penyusun lereng (Faizana, 2015). Gerak tanah terjadi apabila terdapat keadaan ketidakseimbangan yang mengakibatkan bergeraknya sebagian dari lereng mengikuti gaya tarik bumi dan pada akhirnya terjadi longsor. Daerah yang membentuk lahan miring seperti di perbukitan dan daerah pegunungan sangat rawan akan terjadinya gerakan tanah. Suatu lereng dengan kemiringan di atas $20^{\circ}$ memiliki potensi longsor. Namun hal ini juga bergantung pada kondisi geologi lereng tersebut (Khadiyanto, 2010). Kondisi geologi seperti jenis tanah sangat mempengaruhi terjadinya longsor (Setiadi, 2013). Solle dan Ahmad (2016) mengatakan bahwa tanah dengan kandungan mineral liat pada kondisi jenuh air akan menjadi sangat labil, sehingga memperbesar potensi terjadinya longsor.

Kabupaten Bandung Barat yang berada di Provinsi Jawa Barat, sering mengalami bencana longsor dengan rata-rata 67 kejadian per tahun. Hal ini karena wilayahnya yang didominasi oleh perbukitan yang terjal dengan tingkat curah hujan yang cukup tinggi, sehingga Kabupaten Bandung Barat merupakan zona merah rawan bencana longsor.

Kejadian tanah longsor dapat berupa longsoran dalam atau longsoran dangkal. Karakteristik longsoran dangkal adalah kondisi tanahnya tidak stabil pada kedalaman 2 hingga 3 meter (Damanik, 2012). Longsoran dangkal seperti ini sering terjadi di Kabupaten Bandung Barat. Longsoran ini terjadi akibat terbentuknya zona penjenuhan pada lapisan yang berada di dekat permukaan tanah. Terbentuk zona penjenuhan ini akibat turunnya hujan dengan waktu yang relatif lama serta memiliki intensitas sedang hingga tinggi.

Provinsi Jawa Barat merupakan daerah yang menghubungkan ibu kota negara dengan provinsi lainnya di Pulau Jawa. Dengan posisi dan peran yang strategis itu, maka sarana transportasi menjadi penting untuk diperhatikan. Karakteristik daerah Jawa Barat yang didominasi oleh perbukitan menyebabkan sering terjadinya peristiwa tanah longsor yang menutupi badan jalan terutama pada musim hujan. Provinsi Jawa Barat termasuk salah satu daerah di Indonesia yang memiliki potensi tanah longsor tinggi. Selain karena topografi yang berbukit, juga tingginya kepadatan penduduk menimbulkan tekanan terhadap ekosistem.

Oleh karena itu, upaya mitigasi sangat diperlukan dalam menghadapi terjadinya bencana alam terutama bencana longsor sehingga dampak yang timbul dapat dikurangi. Tidak adanya sistem peringatan dini yang dapat menyelamatkan masyarakat dan lingkungan serta minimnya pemahaman tentang lingkungan tempat mereka tinggal, menjadi penyebab banyaknya jatuh korban pada setiap bencana longsor (Rahman, 2010). Upaya mitigasi dapat dilakukan dalam bentuk non struktural, seperti menghindari wilayah bencana dengan cara membangun menjauhi lokasi bencana serta dengan memberdayakan masyarakat dan pemerintah daerah (Jaswadi, 2012).

Pemetaan Risiko Bencana merupakan suatu kegiatan pembuatan peta dengan merepresentasikan dampak negatif yang dapat timbul pada suatu wilayah (Aditya, 2010). Penerapan teknologi informasi spasial berbasis SIG dapat membantu upaya mitigasi dengan melakukan identifikasi dan pengkajian masalah yang timbul akibat bencana longsor. Oleh karena itu, penelitian ini bertujuan untuk memetakan tingkat kerawanan bencana tanah longsor di Kabupaten Bandung Barat, Jawa Barat dengan memanfaatkan informasi spasial berbasis SIG sehingga hasil yang diperoleh nantinya dapat digunakan sebagai salah satu acuan dalam melakukan mitigasi, khususnya pada bencana tanah longsor.

\section{BAHAN DAN METODE PENELITIAN}

Lokasi penelitian pemetaan daerah rawan bencana longsor ini dilakukan di Kabupaten Bandung Barat, Jawa Barat. Bahan dan alat dalam penelitian ini adalah data curah hujan daerah Bandung Barat, data DEM SRTM, peta jenis tanah, peta geologi, peta penggunaan lahan dan data-data pendukung lainnya.

Data-data ini kemudian diinput secara digital melalui perangkat komputer dengan menggunakan software ArcGIS v10.3. Data output yang didapat kemudian digunakan sebagai parameter untuk menentukan dan menganalisis daerah rawan bencana longsor di Kabupaten Bandung Barat. Analisis kerawanan tanah longsor dilakukan dengan melakukan skoring pada parameter yang digunakan, kemudian setelah parameter selesai dilakukan pembobotan pada setiap parameter dengan menggunakan teknik overlay menggunakan software ArcGIS v10.3. Parameter yang digunakan merupakan peta-peta tematik yaitu peta curah hujan, peta geologi, peta tutupan lahan, peta kemiringan lereng dan peta jenis tanah. Setiap parameter ini diklasifikasikan dengan skor tertentu yang kemudian dikali dengan bobotnya berdasarkan model pendugaan Puslittanak 2004. Model pendugaan untuk menganalisis kerawanan tanah longsor mengacu pada penelitian Puslittanak tahun 2004 dengan formula:

$$
\begin{aligned}
\text { Skor Total }= & 0.3 F C H+0.2 F B D+0.2 F K L+ \\
& 0.2 F P L+0.1 F J T
\end{aligned}
$$

Keterangan:

$F C H=$ Faktor Curah Hujan

$F B D=$ Faktor Jenis Batuan

$F K L=$ Faktor Kemiringan Lereng

$F P L=$ Faktor Penggunaan Lahan

$F J T=$ Faktor Jenis Tanah

Hasil dari klasifikasi setiap peta yang dibuat yaitu berupa tabel dengan masing-masing bobot dan skor yang akan ditampilkan pada tabel-tabel di bawah ini: 
Tabel 1. Klasifikasi Curah Hujan (mm/tahun) (Puslittanak, 2004)

\begin{tabular}{lll}
\hline Parameter & Bobot & Skor \\
\hline Sangat basah $(>3000)$ & & 5 \\
Basah $(2501-2300)$ & & 4 \\
Sedang $(2001-2500)$ & $30 \%$ & 3 \\
Kering $(1501-2000)$ & & 2 \\
Sangat kering $(<1500)$ & & 1 \\
\hline
\end{tabular}

Tabel 2. Klasifikasi Kemiringan Lahan (Puslittanak, 2004)

\begin{tabular}{ccl}
\hline Parameter (\%) & Bobot & Skor \\
\hline$>45$ & & 5 \\
$30-45$ & & 4 \\
$15-30$ & $20 \%$ & 3 \\
$8-15$ & & 2 \\
$<8$ & & 1 \\
\hline
\end{tabular}

Tabel 3. Klasifikasi Jenis Batuan (Puslittanak, 2004)

\begin{tabular}{lll}
\hline Parameter & Bobot & Skor \\
\hline Batuan vulkanik & & 3 \\
Batuan sedimen & $20 \%$ & 2 \\
Batuan aluvial & & 1 \\
\hline
\end{tabular}

Tabel 4. Klasifikasi Penutup Lahan (Puslittanak, 2004)

\begin{tabular}{lll}
\hline Parameter & Bobot & Skor \\
\hline Tegalan, sawah & & 5 \\
Semak belukar & 4 \\
Hutan dan perkebunan & $20 \%$ & 3 \\
Kota/permukiman & 2 \\
Tambak, waduk, perairan & & 1 \\
\hline
\end{tabular}

Tabel 5. Klasifikasi Jenis Tanah (Puslittanak, 2004)

\begin{tabular}{lll}
\hline Parameter & Bobot & Skor \\
\hline Regosol & & 5 \\
Andosol, Podsolik & 4 \\
Latosol coklat & $10 \%$ & 3 \\
Asosiasi latosol coklat & & 2 \\
kekuningan & & \\
Aluvial & 1
\end{tabular}

Klasifikasi hasil akhir dilakukan dengan analisis skor dengan membuat 4 kelas kerawanan longsor, yaitu: rendah, sedang, tinggi dan sangat tinggi berdasarkan jumlah skor akhir, semakin besar jumlah skor maka semakin tinggi tingkat kerawanan.

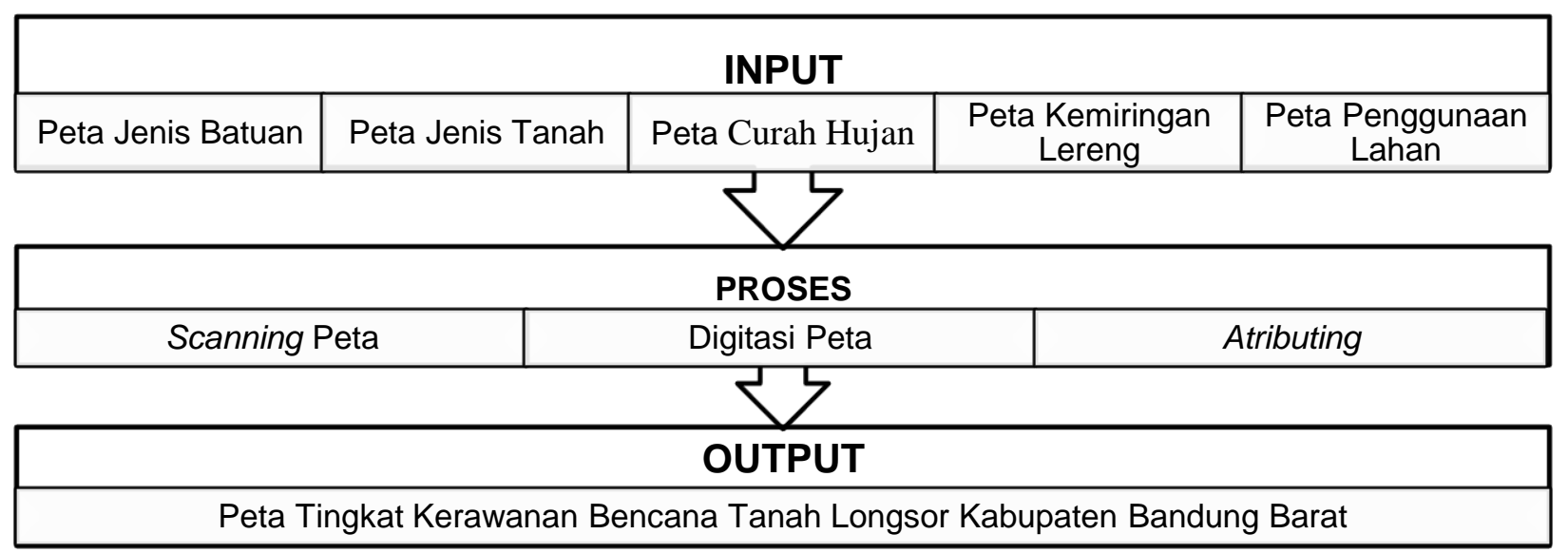

Gambar 1. Diagram Alir Penelitian Pemanfaatan Informasi Spasial Berbasis SIG untuk Pemetaan Tingkat Kerawanan Longsor di Kabupaten Bandung Barat, Jawa Barat.

\section{HASIL DAN PEMBAHASAN}

Secara astronomis Kabupaten Bandung Barat terletak antara $60^{\circ} 41^{\prime}-70^{\circ} 19^{\prime}$ LS dan $107^{\circ}-108^{\circ} 05^{\prime}$ BT dengan ketinggian 768 mdpl. Kabupaten Bandung Barat memiliki perbatasan administrasi dengan Kabupaten Subang dan Purwakarta di bagian utara, kemudian berbatasan dengan Kabupaten Bandung dan Kota Cimahi di bagian timur, dan berbatasan dengan Kabupaten Cianjur di bagian barat.

\subsection{Faktor-faktor yang Mempengaruhi Longsor di Kabupaten Bandung Barat}

Aspek hidrologi sangat diperlukan dalam pengendalian dan pengaturan tata air di suatu wilayah. Dari hasil penelitian diketahui bahwa daerah Bandung Barat memiliki curah hujan yang cukup tinggi. Curah hujan yang tinggi ini tidak didukung oleh kondisi tanah yang tidak mampu menjadi sumber serapan, sehingga air yang masuk ke dalam tanah tidak tertahan dan mengerosi lapisanlapisan tanah yang dilewatinya. Selain itu, topografi DOI: https://doi.org/10.23960/jgrs.2020.v1i1.16 
yang berbukit dengan tingkat kemiringan yang tinggi juga menjadi faktor penting yang mempengaruhi terjadinya longsor. Kondisi alam Kabupaten Bandung Barat yang dominan dengan daerah perbukitan yang cukup terjal juga sangat ber- pengaruh terhadap terjadinya bencana longsor. Kondisi alam pada Kabupaten Bandung Barat menyebabkan potensi bencana di Bandung Barat cukup tinggi, terutama bencana longsor atau pergerakan tanah.
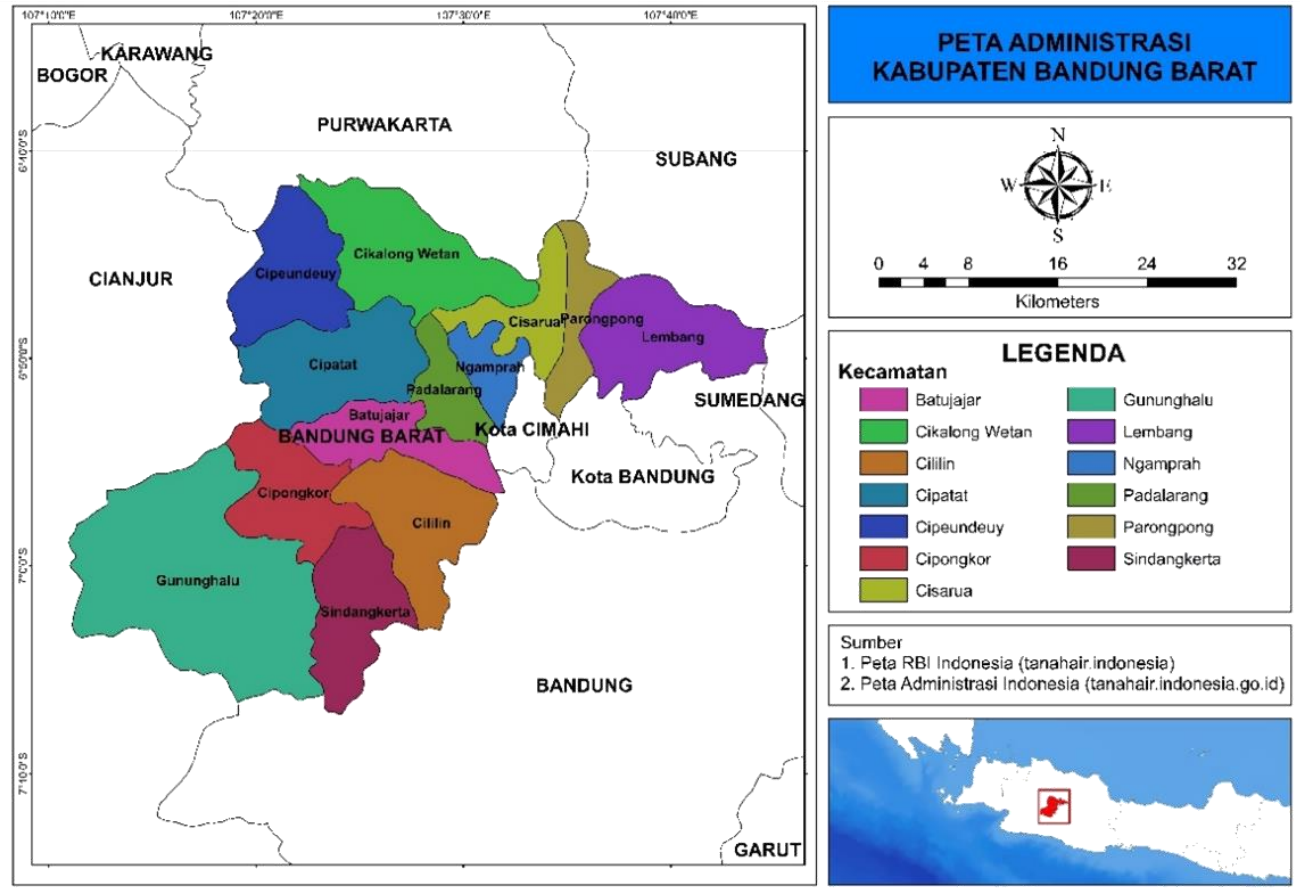

Gambar 2. Peta administrasi kecamatan di Kabupaten Bandung Barat, Provinsi Jawa Barat yang terdiri dari 13 kecamatan.

\subsubsection{Curah Hujan}

Berdasarkan peta curah hujan Kabupaten Bandung Barat yang telah dibuat, curah hujan di lokasi penelitian termasuk tinggi dengan nilai berkisar antara 2500-3000 mm/tahun. Sebagai salah satu parameter dalam menentukan wilayah yang memiliki tingkat rawan longsor. Kemungkinan terjadinya bencana tanah longsor sangat ditentukan
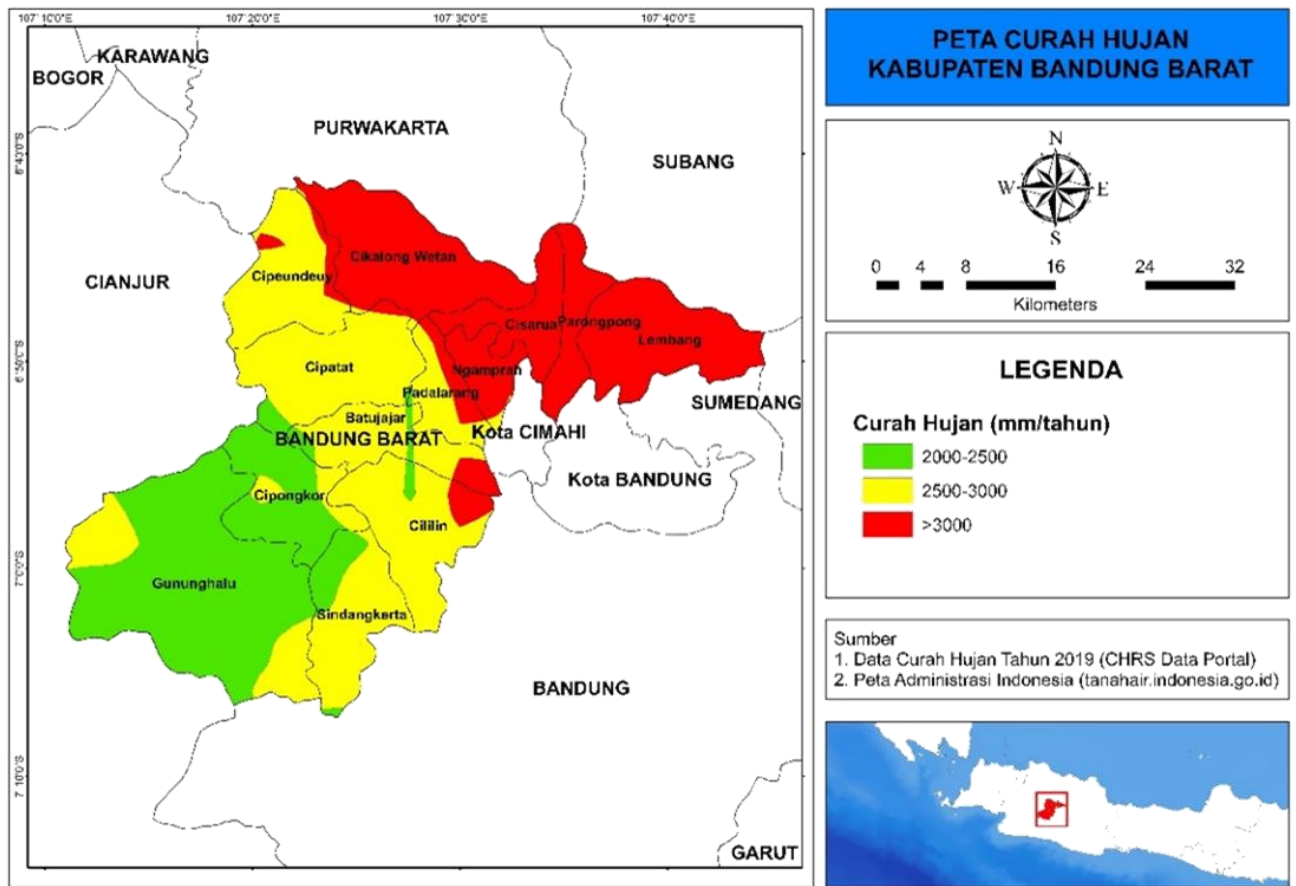

Gambar 3. Peta curah hujan Kabupaten Bandung Barat dengan curah hujan sedang pada rentang 2000$2500 \mathrm{~mm} /$ tahun (warna hijau), curah hujan tinggi pada rentang 2500-3000 mm/tahun (warna kuning) dan curah hujan sangat tinggi pada nilai di atas $3000 \mathrm{~mm} /$ tahun (warna merah). 
oleh intensitas hujan di kawasan penelitian serta distribusi curah hujan di Kabupaten Bandung Barat. Berdasarkan klasifikasi kelas curah hujan Puslittanak, pada lokasi penelitian yang dibahas memiliki tiga pembagian kelas curah hujan yang digunakan yaitu rentang 2000-2500 mm/tahun, 2500-3000 mm/tahun dan >3000 mm/tahun yang dapat dilihat pada Gambar 3 di atas.

Curah hujan dengan intensitas $2000-2500$ mm/ tahun merupakan intensitas curah hujan rendah dengan warna skala hijau yang meliputi dua kecamatan di kabupaten ini, kecamatan tersebut yaitu Gununghalu dan Cipongkor dengan skor 3 karena pada kecamatan tersebut didominasi tingkat curah hujan rendah. Sedangkan pada tabel dapat dilihat bahwa terdapat kecamatan dengan skor 4 yaitu kecamatan Sindangkerta, Batujajar, Cililin, Cipatat, Padalarang, dan Cipeundeuy karena kecamatan tersebut didominasi tingkat curah hujan dengan intensitas tinggi yaitu 2500-3000 mm/tahun ditunjukkan dengan skala warna kuning. Terdapat 5 kecamatan dengan tingkat curah hujan sangat tinggi yang mempunyai intensitas $>3000$ mm/tahun dengan skor 5 terdapat pada kecamatan Cikalong Wetan, Ngamprah, Cisarua, Parompong, dan Lembang ditunjukkan dengan skala warna merah.

\subsubsection{Jenis Batuan}

Sifat setiap batuan berbeda-beda hal ini bergantung pada asal-usul terbentuknya batuan tersebut. Secara umum batuan dipengaruhi oleh tekstur, struktur, kekar, kandungan mineral, cuaca, dan sedimentasi. Berdasarkan pengklasifikasian Puslittanak, batuan pembentuk yang terdapat di lokasi penelitian terdiri dari 3 jenis batuan yaitu batuan Vulkanik, Sedimen dan batuan Aluvial. Secara geologi lokasi penelitian merupakan wilayah dengan struktur batuan yang didominasi oleh batuan vulkanik di mana hal ini dipengaruhi oleh gununggunung yang ada pada Kabupaten Bandung Barat seperti Gunung Tangkuban Perahu. Dengan didominasi oleh batuan vulkanik dan sedimen hal ini menunjukkan bahwa kemungkinan besar batuan sedimen yang berada pada Kabupaten Bandung Barat berasal dari hasil erosi dan pelapukan batuan vulkanik pada wilayah tersebut.

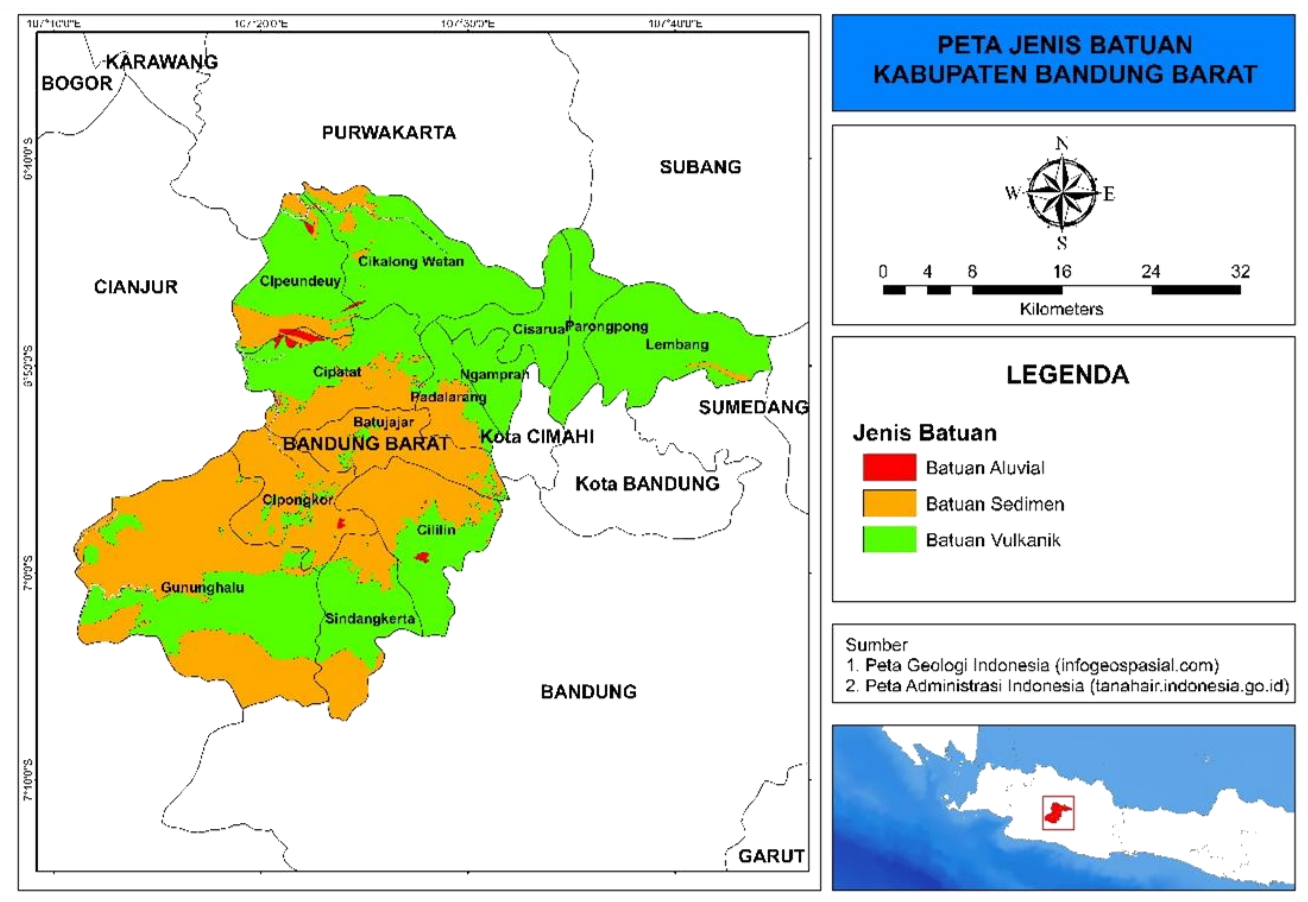

Gambar 4. Peta jenis batuan Kabupaten Bandung Barat yang terdiri dari tiga jenis batuan, yaitu batuan aluvial (warna merah), batuan sedimen (warna jingga) dan batuan vulkanik (warna hijau).

\subsubsection{Jenis Tanah}

Berdasarkan hasil penelitian diketahui bahwa jenis tanah di Kabupaten Bandung Barat terdiri dari tanah Aluvial, Asosiasi Latosol Coklat Kekuningan, Regosol, Andosol, Podsolik dan Latosol Coklat. Mengacu pada klasifikasi Puslittanak berdasarkan kepekaan terhadap erosi, maka jenis tanah di lokasi penelitian terbagi menjadi kelas Sangat Peka
Erosi/Permeabilitas sangat Lambat (Regosol), Peka Erosi/Permeabilitas Lambat (Podsolik, dan Andosol), Agak Peka Erosi/Permeabilitas Cepat (Latosol), dan Tidak Peka Erosi/ Permeabilitas Sangat Cepat (Aluvial dan Lempung). Distribusi spasial jenis tanah di lokasi penelitian dapat dilihat pada Gambar 5. 

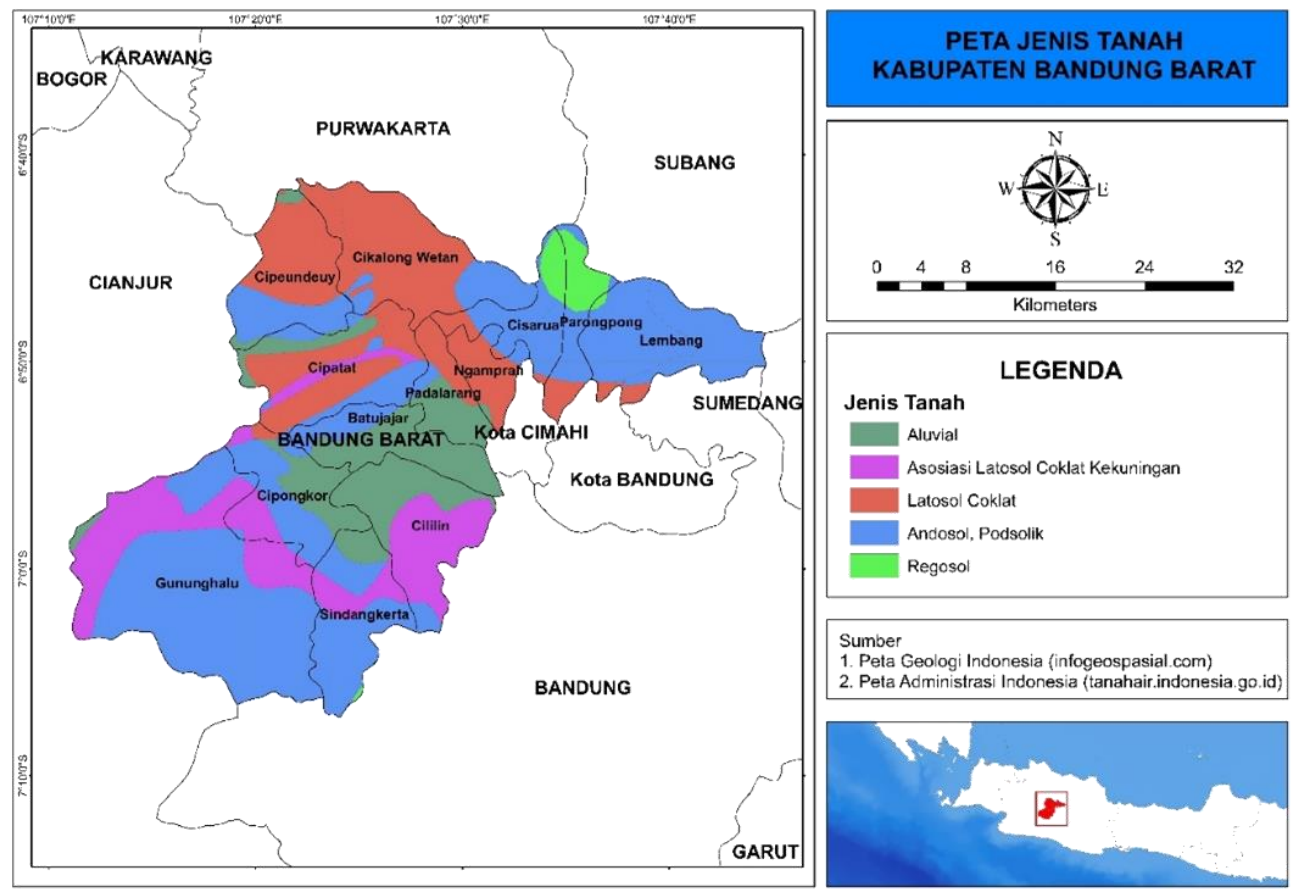

Gambar 5. Peta jenis tanah Kabupaten Bandung Barat yang terdiri dari tanah aluvial, asosiasi latosol coklat kekuningan, latosol coklat, andosol, podsolik dan regosol.

\subsubsection{Penggunaan Lahan}

Berdasarkan hasil digitalisasi peta penggunaan lahan Kabupaten Bandung Barat diperoleh 7 jenis penutupan lahan yang dapat dilihat pada Gambar 6 . Di mana penutupan lahan pada peta ini memiliki kontribusi yang berbeda-beda tergantung pada sifat dan kondisi penutupan lahan tersebut seperti bentuknya berupa danau, hutan, sawah, perkebunan, permukiman, tegalan dan semak belukar. Jenis penutupan serta lokasi penutupan lahan itu berada merupakan hal-hal yang berpengaruh dalam penentuan kerawanan wilayah.
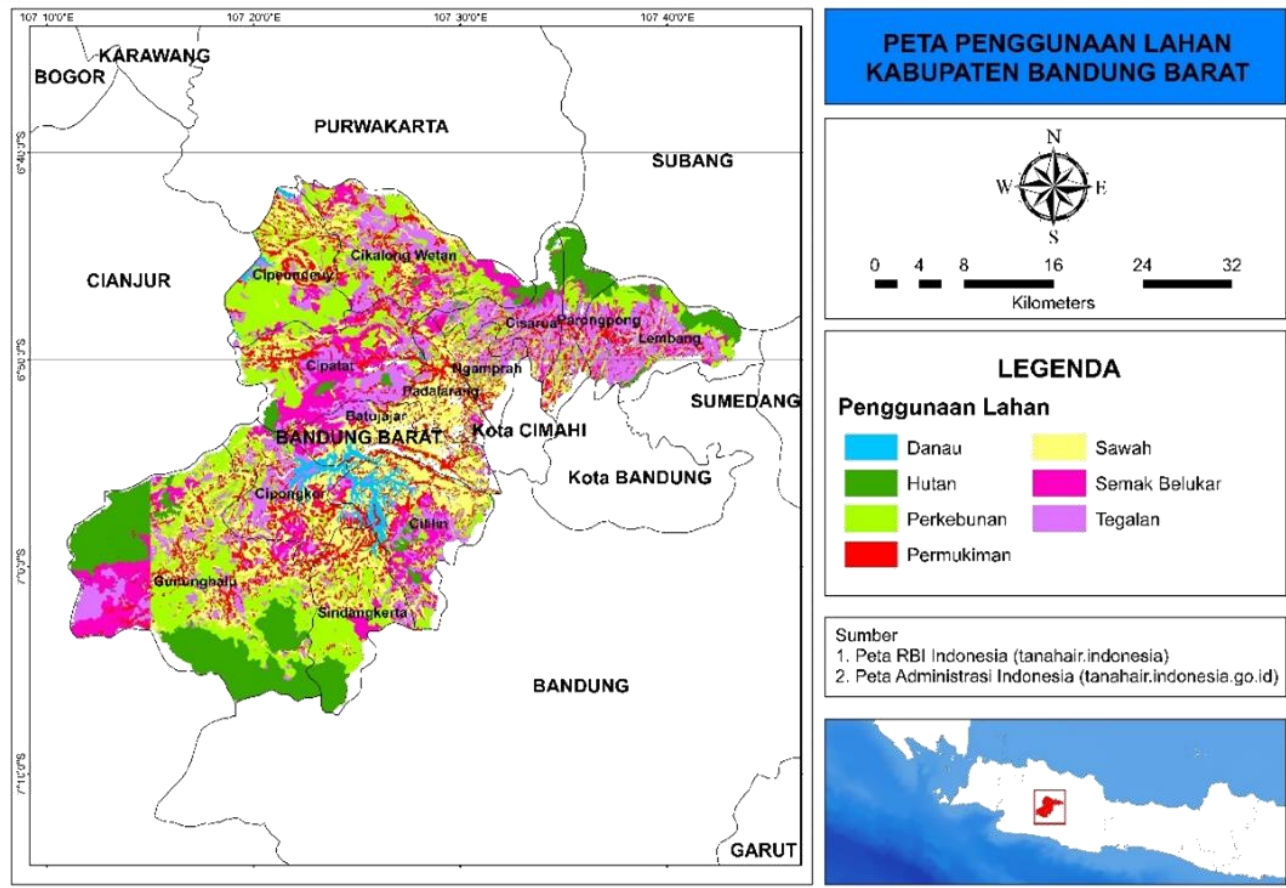

Gambar 6. Peta penggunaan lahan Kabupaten Bandung Barat yang terdiri dari danau, hutan, perkebunan, permukiman, sawah, semak belukar dan tegalan.

\subsubsection{Kemiringan Lereng}

Kemiringan Lahan di lokasi penelitian bervariasi mulai dari datar sampai curam. Berdasarkan hasi klasifikasi maka daerah penelitian memiliki ke- miringan lereng antara lain $>45 \%, 30-45 \%, 15-30 \%$ dan $8-15 \%$ (Gambar 7). Sebelumnya diketahui bahwa kemiringan lahan merupakan salah satu faktor yang dapat memicu longsor (Liu dkk., 2013). 
Semakin tinggi tingkat kemiringan lereng, maka potensi terjadinya longsor juga akan semakin besar. Berdasarkan data pada Gambar 7 dapat diketahui bahwa sebanyak 9 kecamatan yang memiliki kemiringan lereng 15-30\%, 2 kecamatan memiliki kemiringan lereng antara 8-15\%, 11 kecamatan memiliki kemiringan 30-45\%, dan 4 kecamatan memiliki kemiringan lereng $>45 \%$. Secara keseluruhan daerah penelitian memiliki kemiringan dengan kisaran $30-45 \%$ yang merupakan daerah perbukitan.

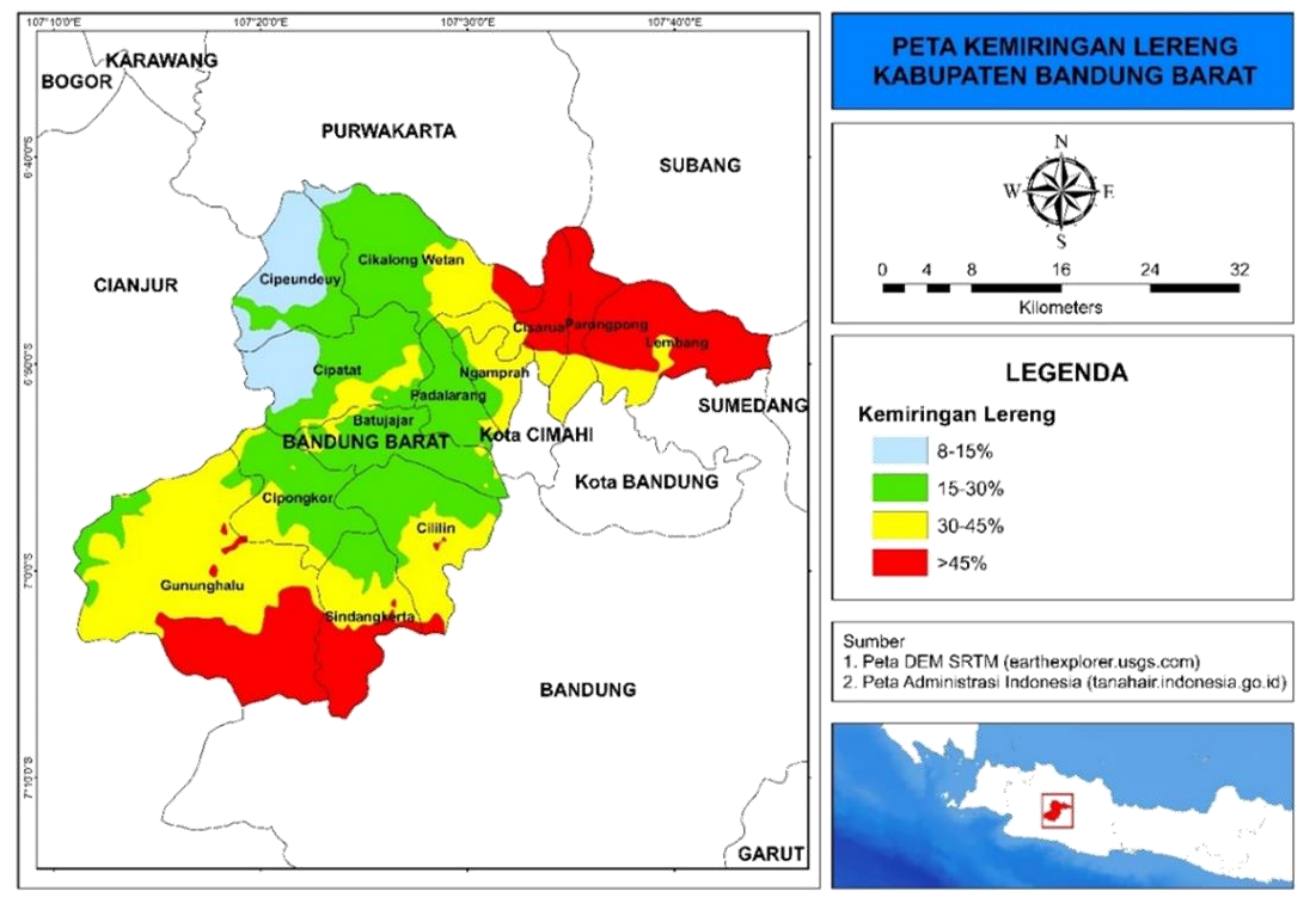

Gambar 7. Peta kemiringan lereng Kabupaten Bandung Barat yang terdiri dari tingkat kemiringan 8-15\% (warna biru muda), kemiringan 15-30\% (warna hijau), kemiringan $30-45 \%$ (warna kuning) dan kemiringan di atas $45 \%$ (warna merah).

\subsection{Pemanfaatan Informasi Spasial berbasis SIG dalam Pemetaan Tingkat Kerawanan Bencana Longsor Di Kabupaten Bandung Barat.}

Berdasarkan peta parameter di atas maka daerah kerawanan longsor dapat ditentukan. Semua parameter tersebut diklasifikasikan berdasarkan skor kemudian diberi bobot sesuai kontribusinya masing-masing dan kemudian data tersebut diolah. Berdasarkan hasil analisis 5 parameter kerawanan longsor dengan menggunakan model Pendugaan Kerawanan Longsor Puslittanak tahun 2004, diperoleh 4 kriteria kerawanan longsor yaitu Sangat Tinggi, Tinggi, Sedang dan Rendah. Sesuai dengan model Pendugaan Kerawanan Tanah Longsor yang bersumber dari Puslittanak tahun 2004 faktor curah hujan mendapat bobot sebesar $30 \%$, faktor jenis batuan, kemiringan lahan dan tipe penutupan lahan dengan bobot $20 \%$, sedangkan faktor jenis tanah memiliki bobot $10 \%$. Berdasarkan penjelasan tersebut, untuk menganalisis kerawanan tanah longsor di lokasi penelitian menggunakan persamaan 1.

Berdasarkan hasil analisis skor total hasil parameter yang ada di lokasi penelitian diperoleh klasifikasi kelas kerawanan dengan interval skor masing-masing kelas seperti tercantum pada Tabel 6.
Tabel 6. Interval Skor Kerawanan Bencana Zona Longsor

\begin{tabular}{cc}
\hline Interval skor $(\%)$ & Kode kerawanan \\
\hline $3.1-4.5$ & Rendah \\
$4.6-6$ & Sedang \\
$6.1-7.5$ & Tinggi \\
$7.5-8.9$ & Sangat Tinggi \\
\hline
\end{tabular}

Setelah didapatkan interval kerawanan bencana longsor tersebut maka dilakukan klasifikasi terhadap peta kerawanan terjadinya bencana longsor pada wilayah penelitian sehingga didapatkan Peta Tingkat Kerawanan Bencana Tanah Longsor di Kabupaten Bandung Barat seperti yang terlihat pada Gambar 8.

Berdasarkan peta tingkat kerawanan bencana tanah longsor di Kabupaten Bandung Barat tersebut diketahui bahwa daerah penelitian memiliki potensi kemungkinan terjadinya bencana longsor yang didominasi tingkat kerawanan sedang hingga tinggi. $\mathrm{Hal}$ ini berkorelasi dengan curah hujan yang tinggi serta kemiringan lereng di beberapa kawasan Bandung Barat serta jenis batuan yang didominasi oleh batuan vulkanik dan sedimen, tentunya kedua batuan tersebut mudah tererosi. 


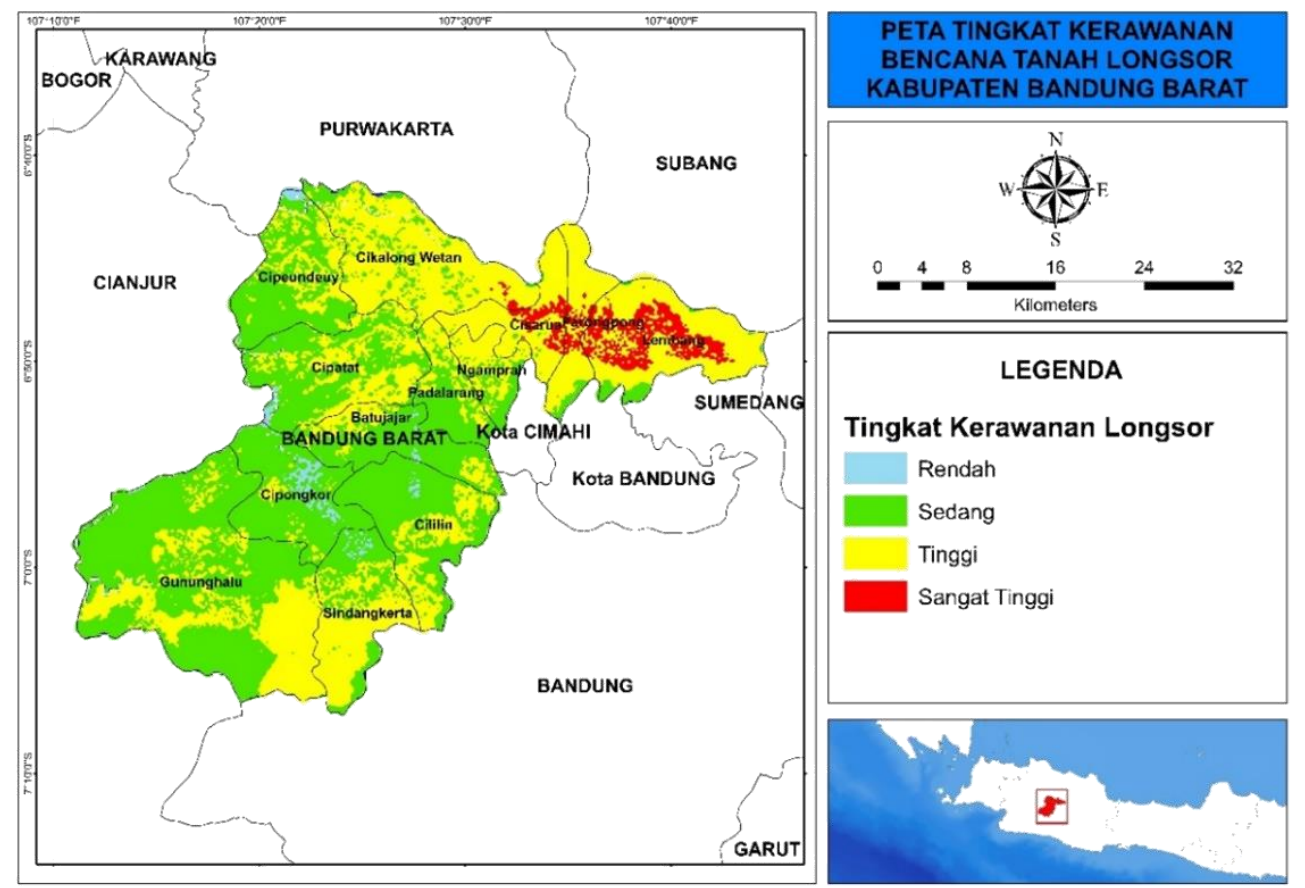

Gambar 8. Peta tingkat kerawanan bencana tanah longsor Kabupaten Bandung Barat yang terdiri dari tingkat kerawanan rendah (warna biru muda), sedang (warna hijau), tinggi (warna kuning) dan sangat tinggi (warna merah).

\section{KESIMPULAN}

Berdasarkan penelitian yang sudah dilakukan maka dapat disimpulkan bahwa terdapat lima faktor utama yang mempengaruhi tingkat kerawanan longsor pada wilayah Kabupaten Bandung Barat di antaranya yaitu jenis tanah, curah hujan, jenis batuan dan penggunaan lahan. Curah hujan pada wilayah penelitian didominasi oleh intensitas yang sedang hingga tinggi berada pada kisaran 2500$3500 \mathrm{~mm} /$ tahun. Jenis tanah yang mendominasi yaitu jenis andosol dan podsolik yang memiliki karakteristik tanahnya gembur, licin, daya absorpsi sedang, memiliki kelembaban yang tinggi karena pada umumnya jenis tanah ini tersebar di daerah yang berdekatan dengan gunung api. Kemudian jenis batuan didominasi oleh batuan vulkanik dan sedimen sebagai hasil atau akibat dari daerah Bandung Barat yang termasuk ke dalam zona bandung. Kemudian zona ini di dominasi oleh kemiringan lereng yang bervariasi pada kisaran 30$45 \%$ hal ini dikarenakan posisi Bandung Barat berada pada daerah pegunungan dan bukit. Kemudian untuk tutupan lahan didominasi oleh tegalan serta pemukiman padat yang menambah kerawanan longsor karena kebanyakan pemukiman dibangun di atas tebing perbukitan.

Hasil dari pemanfaatan SIG ini kita dapat mengetahui bahwa kabupaten Bandung Barat memiliki kategori sedang sampai dengan tinggi Untuk tingkat kerawanan longsor rendah terdapat pada 4 kecamatan, kerawanan longsor sedang pada 7 kecamatan, kerawanan longsor tinggi pada 12 kecamatan, dan kerawanan longsor sangat tinggi pada 3 kecamatan. Potensi terjadinya bencana longsor yang sangat tinggi berada pada
Kecamatan Parongpong, Kecamatan Cisarua dan Kecamatan Lembang. Untuk itu perlu adanya pemahaman edukasi bagi masyarakat tentang mitigasi mengenai daerah yang rawan longsor.

\section{UCAPAN TERIMA KASIH}

Ucapan terima kasih kami ucapkan kepada Badan Informasi Geospasial atas penyediaan data-data yang diperlukan dalam penelitian ini, serta seluruh pihak yang membantu dalam penulisan dan pengolahan data penelitian ini.

\section{DAFTAR PUSTAKA}

Aditya, T. (2010). Visualisasi Risiko Bencana di Atas Peta. Yogyakarta: Fakultas Teknik Geodesi Universitas Gadjah Mada.

Damanik, M. R. S., \& Restu, R. (2012). Pemetaan Tingkat Risiko Banjir dan Longsor Sumatera Utara Berbasis Sistem Informasi Geografis. JURNAL GEOGRAFI, 4(1), 29-42.

Faizana, F., Nugraha, A. L., \& Yuwono, B. D. (2015). Pemetaan risiko bencana tanah longsor Kota Semarang. Jurnal Geodesi Undip, 4(1), 223-234.

Jaswadi, J., Rijanta, R., \& Hadi, M. P. (2012). Tingkat Kerentanan dan Kapasitas Masyarakat dalam Menghadapi Risiko Banjir di Kecamatan Pasarkliwon Kota Surakarta. Majalah Geografi Indonesia, 26(2), 119-149.

Khadiyanto, P., (2010). Gerakan Tanah (Longsoran). Retrieved April 9, 2020, from http://parfikh.blogspot.com/2008/12/gerakan -tanah-longsoran.html 
Liu, C., Li, W., Wu, H., Lu, P., \& Sang, K. (2013). Susceptibility evaluation and mapping of China 's landslides based on multi-source data. Natural Hazards Journal, 69(3), 14771495.

Nugroho, S. P. (2016). Evalusi Penanggulangan Bencana 2015 dan Prediksi Bencana 2016. Jakarta: BNPB.

Pusat Vulkanologi dan Mitigasi Bencana Geologi, (2012). Gerakan Tanah, Bandung: Kementrian ESDM.

Puslittanak Pusat Penelitian dan Pengembangan Tanah dan Agroklimat. (2004). Laporan Akhir Pengkajian Potensi Bencana Kekeringan, Banjir dan Longsor di Kawasan Satuan Wilayah Sungai Citarum-Ciliwung, Jawa Barat Bagian Barat Berbasis Sistem Informasi Geografi. Bogor.

Rahman, A. (2010). Penggunaan Sistim Informasi Geografis untuk Pemetaan Kerawanan Longsor di Kabupaten Purworejo. Bumi Lestari, 10(2).
Rahman, M. W., Purwanto, M. Y. J., \& Suprihatin. (2014). Status Kualitas Air dan Upaya Konservasi Sumberdaya Lahan di DAS Citarum Hulu, Kabupaten Bandung. Jurnal Pengelolaan Sumberdaya Alam Dan Lingkungan, 4(1), 24-34.

Setiadi, T. (2013). Perancangan Sistem Informasi Geografis Pemetaan Daerah Rawan Tanah Longsor, Mitigasi dan Manajemen Bencana di Kabupaten Banjarnegara. Kes Mas: Jurnal Fakultas Kesehatan Masyarakat Universitas Ahmad Daulan, 7(1), 24898.

Solle, M. S., \& Ahmad, A. (2016). Identification of Soil, Rock and Tecto-Volcanism on Landslides in Tondano Watershed. Journal of Geological Resource and Engineering, 6, 271-282.

Sudibyo, N. H., \& Ridho, M. (2017). Pendeteksi Tanah Longsor Menggunakan Sensor Cahaya. Jurnal Teknologi Informasi Magister, 1(02), 218-227. 